\title{
Determinants of Employee Motivation and its impact on Knowledge Transfer and Job Satisfaction
}

\author{
Nida Zafar \\ Department of Management Sciences, The Islamia University of Bahawalpur, Pakistan \\ Email: Nidazafar60@yahoo.com
}

Sana Ishaq

Department of Management Sciences, The Islamia University of Bahawalpur, Pakistan

Email: Sanaishq508@gmail.com

\begin{abstract}
Shaista Shoukat
Department of Management Sciences, The Islamia University of Bahawalpur, Pakistan

Email: Shaista.choudhry42@gmail.com
\end{abstract}

Muhammad Rizwan

Lecturer, Department of Management Sciences

The Islamia University of Bahawalpur, Pakistan

E-mail: rizwan.arshad@iub.edu.pk

Doi:10.5296/ ijhrs.v4i3.5874 URL: http://dx.doi.org/10.5296/ ijhrs.v4i3.5874

\begin{abstract}
This study specifically examines the impact of different variables like extrinsic reward (Pay), intrinsic reward (Appreciation), training and expectancy on employee motivation and impact of employee motivation on job satisfaction and knowledge transfer. The general purpose of this study is to motivate employees. If employees are motivated, they will be satisfied by their jobs and if they are satisfied by their job then they will work hard to attain organizational goals and if goals are achieved then organization will get profit. The current research is descriptive in its nature. We select the sample from different sectors in Pakistan. We select the sample of 200 respondents from population for the collection of data and to check the response of different employees. For this purpose, we structured a selfadministrated questionnaire and filled it from the right respondent for true results. We use
\end{abstract}


Regression analysis in this study. This analysis is very important to check the confidence of the study from different respondents. Due to this analysis, we found that Pay and Appreciation are not directly effecting the employee motivation. Job satisfaction also has no direct link with employee motivation but training of employee, expectancy and knowledge transfer have direct relationship with employee motivation. These three variables help a lot to motivate an employee.

Keywords: Pay, Appreciation, Expectancy, Training, Job Satisfaction and Knowledge Transfer.

\section{Introduction}

Now a day, because of competition in businesses, organizations are facing many challenges. From these challenges, keeping their human resource is of most importance. Today, humans are considered to be the most important resources of an organization. Employee motivation is compulsory for getting efficiency. Motivation is a group of different items which effects employee's behavior for getting required goal. Motivation is important to boost up employees to perform well in long run and helps an organization to grow for excellence. Motivating the people is not an easy step.

The general purpose of this study is to motivate employees. Motivated employees help organization to survive. Motivating employees is more fruitful for an organization. Managers have to understand which thing will help much to motivate employees. Among all the roles of a manager, motivating employees is uncertainly very complicated. If employees are motivated, they will be satisfied by their jobs and if they are satisfied by their job then they will work hard to attain organizational goals and if goals are achieved then organization will get profit. Specifically, this study describes the impact of different rewards (extrinsic rewards and intrinsic rewards), expectancy and training on employee motivation and impact of employee motivation on knowledge transfer and job satisfaction. Rewards are of 2 types:

\section{Extrinsic rewards}

\section{Intrinsic rewards}

Extrinsic rewards are tangible in nature. They can be in the form of salary/pay, incentives and bonuses. Intrinsic rewards are intangible like appreciation, caring attitudes from employer and job rotation. Rewards have also been defined as monetary and non-monetary rewards. Monetary rewards are tangible like promotion, bonuses etc. Non-monetary rewards are intangible like praise and person's recognitions. Many authors argue that monetary and non-monetary rewards are considered as extrinsic rewards. Intrinsic non-monetary rewards refer to the rewards that are intangible in nature and extrinsic non-monetary rewards are tangible like social rewards.

The opinion of performance management has given a reward system which know the needs of employees and goals which an organization wants to get. The system also said that training and development of employees is needed to motivate them. This training or development 
opinion of employees gives them intrinsic motivation. An organization must have a reward system to appraise the performance of employees and then rewarding them. For employees to work together efficiently knowledge transfer is also important. To generate extrinsic and intrinsic motivation managers are motivated to make best use of knowledge transfer. When economy expands, it moves towards globalization. In the global economy enormous number of competitor organization need many kinds of solution. Many factors create difficulty for the organization when global crisis arise, firms need to change the organization system. The main focus of organization is to invest their employees in form of rewards in search of development, motivation and increase in the performance of human resources. According to the Barber and Bretz (2000) the reward management system has impact on to motivation to retain the employees to perceive high level of performance.

Expectancy is defined as that effort will lead to good performance. Expectancy is that one's effort will take to better performance is based on past knowledge and self-confidence. In the global economy to meet the competitor manager involves highly train workforce to acquire the goals. There must be HR practice motivate and provide best place to the work. According to (Meyer and Allen, 1991) training directly or indirectly effect the motivation and loyalty of an employee for his organization .Companies invest their employees to assure the skills which help out not in present but also in future.

Increasing competition forces companies need to have highly skilled, motivated and loyal employees who work for the success of the company. So motivation of these employees is requirement of the company. Committed and loyal employees work at their best for organization' success. Job satisfaction is the employee's opinion that how much they are satisfied with their job. It is positive and emotional state resulting from evaluation of one's job. Existence of enterprises and their success are affected by quality of human resources. Therefore motivation of employees is necessary for developing an organization.

\section{Literature review}

\section{Employee motivation}

Reflection of level of energy, commitment and creativity that a company's workers bring to their jobs. Motivation is an emotional feature that encourages an employee to act towards a desired goal. Employee motivation means to motivate employees by giving rewards to them to attain the organizational goals.

The individual motivation of employees plays an important role in getting high level satisfaction (Petcharak, 2004). Motivation is a process in which people are influenced to move onwards for performing something especially to fulfill their needs and get satisfaction (Butkus and Green, 1999). Baron (1893) defined motivation in his own right. He says "motivation is a collection or arrangements of procedures involved in push and pull forces that makes the actions stronger towards success". Kinicki and Kreitner (2001) assume that motivation corresponds to such emotional processes that cause the inspiration and determination of voluntary actions that helps to attain the goals. Rutherford (1990) found in his research that motivation is the effective agent in an organization because; motivated 
employees are always innovative in their jobs. It is task for the organization to appreciate and understand the procedures necessary to have an effect on encouragement of their workers. The majority of theorists in the area of motivation argue that, there is an unquestionable link between motivation and job satisfaction and motivation with employee loyalty to the organization (Basset-Jones and Lloyd, 2005; Chen et al., 2004; Lok and Crawford, 2004; Pool and Pool, 2007). Sirotaet al. (2005), in a major study of motivation and job satisfaction, involving 135,000 respondents from different countries and groupings, found that organizations employing motivation strategies, that include three major things, i.e. justice, companionship and achievement. Barber and Bretz (2000) mentioned that reward management systems have major impact on organizations ability to catch, retain and motivate high potential employees and as a result getting the high levels of performance.

\section{Extrinsic reward}

Extrinsic rewards are tangible and are exterior to work and efficiency of the employees. Salary/pay, incentives and bonuses are the types of extrinsic rewards. Pay has direct link with efficiency of the employee (Bishop, 1987). There must be a successful extrinsic reward system to get better performance and high efficiency of the employees (Carraher, 2006). Extrinsic rewards as tangible rewards obtained due to doing the job, such as pay and promotion (Porter and Lawler, 1968). Mottaz (1985) says that extrinsic rewards are also defined as social and organizational rewards. Organizational rewards are like pay, bonuses and fringe benefits which can be seen (Katz \& Van Maanen, 1977; Malhotra et al., 2007; Mottaz, 1985). Whilst Kuvaas (2006) said that employee's loyalty depends upon pay and bonuses given to them. Social rewards help employees to create interest for achieving company's objective (Burke, 2002). Reio and Callahon (2004) conclude that extrinsic rewards motivate the employee and obtain high efficiency from them. Many researches were conducted by Professor Elton Mayo who said that motivating employees is the main work of an organization. Frey (1997) argues that pay plays an important role in motivating the employees. He also argues that if bonuses and incentives are given to the employees, they will be satisfied and motivated and work hard to obtain the organizational goal.

\section{H1: There is a positive impact of extrinsic rewards (Pay) on employee motivation.}

\section{Intrinsic rewards}

Intrinsic rewards are intangible in nature. We cannot touch them with our hands but only feel them such as appreciation, caring attitudes from employer and job rotation. Intrinsic rewards are the rewards within the job itself such as satisfaction from completing a task, appreciation from employer (Ajila, 2004). Loyalty of employees depends upon rewards and recognition (Andrew, 2004). Porter and Lawler (1968) said that the satisfaction which an employee gains by doing his work is intrinsic reward. Mottaz (1985) said that intrinsic rewards are of different kinds. Task rewards are example of it and they refer duties and responsibility of an employee. Intrinsic non-monetary rewards can also be defined as the appreciation which an 
employee gets by his or her efforts by completing his job (Porter \& Lawler, 1968). Malhotra et al. (2007) explained that intrinsic non-monetary rewards influence the loyalty of an employee more effectively than extrinsic rewards. Adeyemo and Aremu (1999), said that employer who is more helpful to his employees is also a big reason of employee loyalty. Burke (2002) said that if controllers are loyal to their employees and behave nicely with them than employees will be more loyal to their employers and their jobs. Reio and Callahon (2004) argued that intrinsic rewards are used to motivate employees for higher efficiency. Dee prose (1994) said that intrinsic rewards are very effective for getting motivation and efficiency of employees. So, they will work better for organization. The overall success of an organization depends on how an organization motivates its employees and how they differentiate their performance. Lawler (2003) said that success of the organizations depends on how they motivate their employees. Many researches were conducted by Professor Elton Mayo who said that motivating employees is the main work of an organization.

\section{H2: There is a positive impact of intrinsic rewards (Appreciation) on employee motivation.}

\section{Training effectiveness}

On Organization commitment and employee motivation the training producers used by companies both have direct and indirect effect (Meyer and Allen, 1991) "A intrusion system is developed to increase the job performance on individual basis" (Chiaburu and Tekleab, 2005, p. 29).

According to Swart et al. (2005) the motivation of the individual, the individual's needs and training system are the source of individual improvement. The mainstream of theorists in the area of motivation argue that, there is an undeniable link between motivation with employee commitment to the organization and motivation.(Basset-Jones and Lloyd, 2005; Chen et al., 2004; The fear occur during job performance due to lack of skills unfavorable causes ,lack of communication skill, annoyance and other factors to control situations and increase work productivity training is much important (Chen et al., 2004). Row den and Connie (2005), through training the organization employee know well how to satisfy their customer. Tsai et al. (2007), when employees are trained and satisfy their jobs and loyal to their organization will show a positive effect on organizational goals. According to Harrison (2000), training is main component and his key factor learning also help the organization to achieve their objective and goals would create a positive effect. In general, it can be argued that the outcome or results the organization is expected usually are low. According to few studies employee's thoughts moreover change through training. Lang (1992) argued the training system developed by the organization help to increase the productivity of employees and achieve goals. Another survey, conducted by Gaertner and Nollen (1989) in manufacturing firms, concealed employee loyalty linked with the concealed HRM methods. These methods were inner encouragement, and training opportunity. 
H3: There is a positive impact of perceived training effectiveness on employee motivation.

\section{Expectancy}

Expectancy is the apparent chance that effort goes to good presentation; variables affecting the individual's expectancy discernment include self-efficacy, goal difficulty, and perceived control. We get the targeted performance through expectancy the basis of experience and knowledge. Expectancy usually is supported by tentative verification (Tien, 2000; Vansteenkiste et al., 2005) and it is normally used theories of motivation in the workplace/organization (Campbell and Pritchard, 1976; Henemne and Schwab, 1972; Mitchell and Biglan, 1971) employee motivation play important role in job performance, both the academy and hotel industry be renowned with the significance of motivating.

The organization are aware of key factors that motivate their employees and give them long term benefits which help in present and future both. (Simons and Enz, 1995; Siu et al., 1997; Wong et al., 1999). Through expectancy we made general criteria for evaluating, check the employee performance toward employee behavior to perform certain job, making decision and achieving goals. (Chen and Lou, 2002).However, Mitchell (1974) the components of expectancy will help to learn about validity. In concurrence with expectancy many different methods, producer statistical tools are used, but a main alarm remains: that the validity of the expectancy remains unclear and vague (Van Eerde and Thierry, 1996). Landy and Becker (1990) suggested that the factors to improve the prediction of an expectancy model capacity stretch out in variables such as the number of outcomes or results, the valence of the outcomes, and the particular reliant changeable selected for learning.

\section{H4: There is a positive impact of expectancy on employee motivation.}

\section{Job satisfaction}

Job satisfaction is the pleasant or positive state that one has from his/her job experience. It is employees perception that how much their expectations have fulfilled they have from their job (Locke, 1976). Job satisfaction is the state that how much output meets or exceeds our expectations and it represents the most important attitudes like work itself, salary, promotion opportunities, supervision and coworkers and people show positive responce about it(Luthans, 1998).Absence of job satisfaction can be reason of lack of interest and organizational commitment (Moser, 1997). Dissatisfaction is the big cause for employees to leave the job and they are more absent than satisfied employees (Rusbultet al, 1988).Job satisfaction can be linked with employee motivation. Satisfied employees spend more time to understand their work. The employees who are satisfied with the job adapt both changes in circumstances either bad or good. As result those who enjoy their jobs are expected to have strong motivation or vice versa. 


\section{Macrothink \\ International Journal of Human Resource Studies \\ ISSN 2162-3058 2014, Vol. 4, No. 3}

H5: There is a positive impact of employee motivation on job satisfaction.

\section{Knowledge transfer}

To enable employees to work together efficiently knowledge transfer is essential. To increase the organization efficiency managers should encourage their employees. Employee motivation cannot be controlled on profit. Employees transfer their knowledge related to their individual learning when they are intrinsically motivated (Huysman and de Wit, 2004).Employee motivation has two important roles in knowledge transfer. First it is reward of process itself and second it is the source of enhancing individual participation of knowledge (Lucas and Ogilvie, 2006).

H6: There is a positive impact of employee motivation on knowledge transfer process.

\section{Research Model}

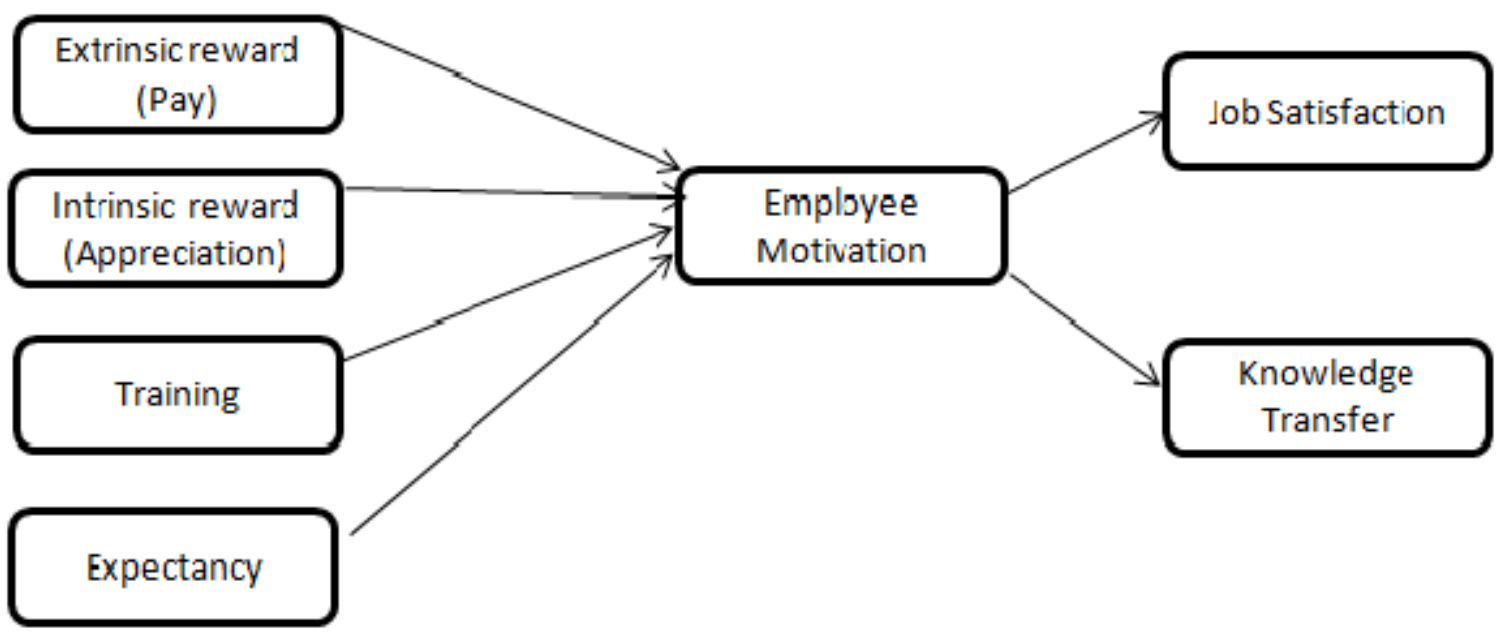

Figure.1 


\section{Research methodology}

This study is descriptive in nature. Descriptive research is defined as anything that is interesting for the observer. Descriptive research nature is used to explain or describe the existing situation with some scales and proofs rather than using judgment and perception about the situation (Creswell, 1994). Descriptive research is mainly used for the conformation of newly developed model or hypothesis. This hypothesis will reflect existing situation. Researchers use this research to explain present phenomenon and will kept focus on past research or modern thinking.

\section{Sample \&Data}

The main purpose of this study is to explain the current situation of different variables on employee motivation. We select the sample from different sectors in Pakistan. This study is purely conducted from employees. We select the sample of 200 from population for collection of data and to check the response of different employees. For this purpose, we structured a self- administrated questionnaire and filled it from the right respondent for true results.

For true results, we use the non-probability sampling which also known as convenience sampling. Purpose of sampling method is to acquire and gather the appropriate information from relevant sample according to availability which is known as "convenience sampling" (Zikmund, 1997). This technique is usually used to cover a large no. of population to see the overall impact of variables (Lym et al, 2010).

Before collection of data and filling the questionnaire, we made conditions for our selected sample which are as follows:

- They should be employee of some public or private organization.

- Respondent should be belonging of Pakistan.

Our sample should have to follow these conditions to participate in self-administrated questionnaire. It will reduce the biasness in result and also increase the reliability of results.

We select our sample from different sectors of Pakistan. The response rate of respondents was 80 percent which is a good rate and reliable for results as compare to the several previous studies on the similar topic. Our sample was mostly employee of middle level and low level in organization hierarchy. The survey was conducted through personal visits. We also assure from respondent about his willingness to take part in activity before handing over the questionnaire to them.

We select this sample from different public or private organizations and institutes of Pakistan. The selection of employees is based on the previous results of the studies on employee motivation. Motivation is a process in which people are influenced to move onward for performing something especially to fulfill their needs and get satisfaction (Butkus and Green, 1999). Baron (1893) defined motivation in his own way. He says "motivation is a collection or arrangements of procedures involved in push and pull forces that makes the actions 
stronger towards success".

\section{Instruments and measures}

The item of each variable are taken from previous highly authenticate and proof researches.

The related instruments for currently study focus on major intentions which are as follows:

Main use of this study is to see the relationships between different variables to see the motivation of employees in reality.

- Collect information about current situation in organizations.

- To see the variation in motivation from last researches.

- Collect information about different features of respondents.

The questionnaire contains two sections:

Section 1: It contains personal and demographic information of different respondents. This information is all about gender, age, income and type of organization.

Section 2: It contains the questions about employee motivation in any organization. This section consists of latent variables which are basic measures in current study. The variables are employee motivation, extrinsic reward (Pay), intrinsic reward (appreciation), training, expectancy, job satisfaction and knowledge transfer. We developed this section with the help of past literature and we used questionnaire.

Every item of this questionnaire is taken by past literature and also published researches. The main variables of the model and their references are given in this table.

Table 1: Scales of study

\begin{tabular}{|c|c|c|c|}
\hline No. & Variables & Items & References \\
\hline 1 & $\begin{array}{l}\text { Employee } \\
\text { Motivation }\end{array}$ & $\begin{array}{l}\text { 1. I feel a sense of personal motivation when I do this } \\
\text { job well. } \\
\text { 2. My opinion of myself goes down when I do the job } \\
\text { badly. } \\
\text { 3. I take pride in doing my job as well as I can. } \\
\text { 4. I feel unhappy when my work is not up to my usual } \\
\text { standard. } \\
5 \text {. I like to look back at a day's work with a sense of a } \\
\text { job well done. } \\
6 \text {. I try to think ways of doing my job effectively. }\end{array}$ & $\begin{array}{l}\text { Butkus and } \\
\text { Green, } 1999 \\
\text { Baron, } 1893\end{array}$ \\
\hline
\end{tabular}




\begin{tabular}{|c|c|c|c|}
\hline 2 & Pay & $\begin{array}{l}\text { 1. I am satisfied with the existing salary structure of the } \\
\text { company. } \\
\text { 2. I am satisfied with the compensation I get \& I think it } \\
\text { matches with my responsibility. } \\
\text { 3. My salary structure is revised annually. } \\
\text { 4. I get salary according to the duties I perform on the } \\
\text { job. }\end{array}$ & Bishop, 1987 \\
\hline 3 & Appreciation & $\begin{array}{l}\text { 1. I am happy with my work responsibilities. } \\
\text { 2. I am happy with the recognition and rewards for my } \\
\text { outstanding work and contribution. } \\
\text { 3. I am appreciated by my boss for any extra work } \\
\text { which I do. }\end{array}$ & Ajila, 2004 \\
\hline 4 & Training & $\begin{array}{l}\text { 1. My company provides me the opportunity to improve } \\
\text { my skills. } \\
\text { 2. There is lot of chance to learn new things in this } \\
\text { company. } \\
\text { 3. My company frequently arranges training programs } \\
\text { for the employees. } \\
\text { 4. Doing job in this company will benefit me in the } \\
\text { future. }\end{array}$ & $\begin{array}{l}\text { Chiaburu } \quad \& \\
\text { Tekleab, } 2005\end{array}$ \\
\hline 5 & Expectancy & $\begin{array}{l}\text { 1. If I work very hard, my job performance will } \\
\text { significantly improve. } \\
\text { 2. If I work very hard, I will get a lot more accomplish. } \\
\text { 3. If I put more effort into my job, my productivity will } \\
\text { improve significantly. } \\
\text { 4. If I put more effort into my job, I will definitely be } \\
\text { regarded as effective employees. }\end{array}$ & Vroom , 1964 \\
\hline 6 & Job Satisfaction & $\begin{array}{l}\text { 1. My basic salary is sufficiently paid according to my } \\
\text { daily working hours and workload. } \\
\text { 2. I am satisfied with my chances for salary increases. } \\
\text { 3. The work I do is appreciated. } \\
\text { 4. I believe those that do well on the job have fair }\end{array}$ & $\begin{array}{l}\text { Luthans, } 1998 \\
\text { Moser, } 1997\end{array}$ \\
\hline
\end{tabular}




\begin{tabular}{|c|c|c|c|}
\hline & & $\begin{array}{l}\text { chances of being promoted. } \\
5 \text {. It is possible to get promoted fast in my job. }\end{array}$ & \\
\hline 7 & $\begin{array}{l}\text { Knowledge } \\
\text { Transfer }\end{array}$ & $\begin{array}{l}\text { 1. I feel secure when sharing information and } \\
\text { know-how with my colleagues. } \\
\text { 2. I know precisely who in the company has the specific } \\
\text { know-how that can help me with my work. } \\
\text { 3. I have access to people who have the tacit know-how } \\
\text { I require, irrespective of their hierarchal level. } \\
\text { 4. The company rewards the results of teamwork } \\
\text { performed. } \\
\text { 5. When I need to obtain specific know-how, the } \\
\text { company designates a specialist to assist me. } \\
\text { 6. When I need some know-how, the company } \\
\text { encourages me to attempt to obtain it from other } \\
\text { employees. } \\
\text { 7. When I need some know-how, the company } \\
\text { encourages me to attempt to obtain the company } \\
\text { possesses. } \\
\text { 8. Know-how is not the source of power in the } \\
\text { company. } \\
\text { 9. The in-company culture favors questioning the work } \\
\text { of colleagues. } \\
\text { 10. My colleagues and superiors appreciate the } \\
\text { suggestions and ideas that I put forward based on my } \\
\text { own know-how, even when I don't have sufficient } \\
\text { information to back them up. } \\
\text { 11. A medium that I use most to interact with people in } \\
\text { the company whose know how is important for my } \\
\text { work is personal conversation. }\end{array}$ & $\begin{array}{l}\text { Lucas and } \\
\text { Ogilvie, } 2006\end{array}$ \\
\hline
\end{tabular}

\section{Procedure}

The structured questionnaire was distributed among 200 respondents in Lahore, Bahawalpur, Sadiq Abad, Haroon Abad, Multan and Karachi. The entire respondents were selected on their 


\section{Macrothink}

International Journal of Human Resource Studies

ISSN 2162-3058

2014, Vol. 4, No. 3

willingness and on their ease. These respondents were also fulfilling the features of above mentioned variables and their items. Firstly, we explain the whole criteria and all questions to the respondents for their conveniences and easiness for filling the questionnaire. We also told the purpose of this study and its impact was positive. We select 160 questionnaires for future procedure and reject 40 questionnaires for some confusion or incomplete response. After collection and arranging the questionnaire, we started entering the data into SPSS for final analysis and results.

\section{Reliability analysis}

This analysis is very important to check the assurance of the study from different respondents. In reliability, we will check the cronbach's alpha of every variable separately. The limits of cronbach's alpha decided by Nunally (1970) which is 0.50. After this Moss et al (1998) decide the limit for every variable 0.60 . The cronbach's alpha of every variable is as follow:

Table 2: Reliability of measurement instruments

\begin{tabular}{|l|l|l|}
\hline Scales & \multicolumn{1}{|c|}{ Items } & Cronbach's alpha \\
\hline Employee Motivation & 6 & 0.621 \\
Pay & 4 & 0.703 \\
Appreciation & 3 & 0.676 \\
Training & 4 & 0.742 \\
Expectancy & 4 & 0.696 \\
Job Satisfaction & 5 & 0.767 \\
Knowledge Transfer & 11 & 0.819 \\
& & \\
\hline
\end{tabular}

By seeing table, we can conclude that all variables have cronbach's alpha more than limit of reliability. Every variable is acceptable and their reliability is ideal for further results. This table shows that all the 37 items of different variables are valid and much suitable to measure the attitude of employee towards motivation in organizations. 


\section{Macrothink \\ International Journal of Human Resource Studies \\ ISSN 2162-3058 \\ 2014, Vol. 4, No. 3}

\section{Result and Analysis}

\section{Profiles of the respondents}

Here is the table of personal information about respondent. This respondent selection was according to our requirements and specifications.

Table 3: Profile of Respondents

\begin{tabular}{|c|c|c|c|}
\hline & Category & Frequency & Percentage \\
\hline Variables & & & \\
\hline Gender & $\begin{array}{l}\text { Male } \\
\text { Female }\end{array}$ & $\begin{array}{l}91 \\
69\end{array}$ & $\begin{array}{l}56.9 \\
43.1\end{array}$ \\
\hline Age & $\begin{array}{l}\text { Below } 20 \text { years } \\
20-30 \text { years } \\
30-40 \text { years } \\
\text { Above } 40 \text { years }\end{array}$ & $\begin{array}{l}28 \\
90 \\
32 \\
10\end{array}$ & $\begin{array}{l}17.5 \\
56.3 \\
20.0 \\
6.3\end{array}$ \\
\hline Income & $\begin{array}{l}\text { Below } 10,000 \\
10,000-20,000 \\
20,000-30,000 \\
30,000-40,000 \\
\text { Above 40,000 }\end{array}$ & $\begin{array}{l}56 \\
48 \\
41 \\
2 \\
13\end{array}$ & $\begin{array}{l}35.0 \\
30.0 \\
25.6 \\
1.3 \\
8.1\end{array}$ \\
\hline Organization & $\begin{array}{l}\text { Public } \\
\text { Private }\end{array}$ & $\begin{array}{l}89 \\
71\end{array}$ & $\begin{array}{l}55.6 \\
44.4\end{array}$ \\
\hline
\end{tabular}

\section{Hypotheses Testing}

\section{Pay and employee motivation}

According to the Regression results of the study, there is a positive insignificant relationship between pay and employee motivation. Pay has $\beta=0.001$ and $\mathrm{p}=0.995$. Therefore, $\mathrm{H} 1$ is rejected.

\section{Appreciation and employee motivation}

According to the Regression results of the study, there is a positive insignificant relationship 


\section{Macrothink}

between appreciation and employee motivation. Appreciation has $\beta=0.060$ and $p=0.498$. Therefore, $\mathrm{H} 2$ is rejected.

\section{Training and employee motivation}

According to the Regression results of the study, there is a positive significant relationship between training and employee motivation. Training has $\beta=0.185$ and $p=0.045$. Therefore, $\mathrm{H} 3$ is accepted.

\section{Expectancy and employee motivation}

According to the Regression results of the study, there is a positive significant relationship between expectancy and employee motivation. Expectancy has $\beta=0.220$ and $p=0.018$. Therefore, H4 is accepted.

There is $\mathbf{1 2 . 7 \%}$ variation in employee motivation due to Pay, Appreciation, Training and Expectancy.

\section{Job Satisfaction and employee motivation}

According to the regression results of the study, there is a positive insignificant relationship between employee motivation and job satisfaction. Job satisfaction has $\beta=0.105$ and $p=0.188$. Therefore, H5 is rejected. There is $\mathbf{0 . 5 \%}$ variation in job satisfaction due to employee motivation.

\section{Knowledge Transfer and employee motivation}

According to the regression results of the study, there is a positive significant relationship between employee motivation and Knowledge Transfer. Knowledge Transfer has $\beta=0.259$ and $\mathrm{p}=0.001$. Therefore, H6 is accepted. There is $\mathbf{6 . 1 \%}$ variation in knowledge transfer due to employee motivation. 


\section{Ml Macrothink}

International Journal of Human Resource Studies

ISSN 2162-3058

2014, Vol. 4, No. 3

Table 4: Regression Results

\begin{tabular}{|c|c|c|c|c|c|c|}
\hline $\begin{array}{l}\text { Hypot } \\
\text { hesis }\end{array}$ & variables & $\begin{array}{l}\text { Estimate } \\
\mathrm{S}\end{array}$ & S.E & C.R & $\mathbf{P}$ & Results \\
\hline H1 & $\begin{array}{l}\text { Employee Motivation } \\
\text { Pay }\end{array}$ & 0.001 & 0.053 & 0.007 & 0.995 & $\begin{array}{l}\text { Not } \\
\text { supported }\end{array}$ \\
\hline H2 & $\begin{array}{l}\text { Employee Motivation } \\
\text { Appreciation }\end{array}$ & 0.060 & 0.062 & 0.679 & 0.498 & $\begin{array}{l}\text { Not } \\
\text { supported }\end{array}$ \\
\hline H3 & $\begin{array}{l}\text { Employee motivation } \\
\text { Training }\end{array}$ & 0.185 & 0.066 & 2.023 & 0.045 & Supported \\
\hline H4 & $\begin{array}{l}\text { Employee motivation } \\
\text { Expectancy }\end{array}$ & 0.220 & 0.072 & 2.382 & 0.018 & Supported \\
\hline H5 & $\begin{array}{l}\text { Job Satisfaction } \\
\text { Employee Motivation }\end{array}$ & 0.105 & 0.116 & 1.321 & 0.188 & $\begin{array}{l}\text { Not } \\
\text { supported }\end{array}$ \\
\hline H6 & $\begin{array}{l}\text { Knowledge Transfer } \\
\text { Employee Motivation }\end{array}$ & 0.259 & 0.088 & 3.372 & 0.001 & Supported \\
\hline
\end{tabular}

\section{Research Model Results}

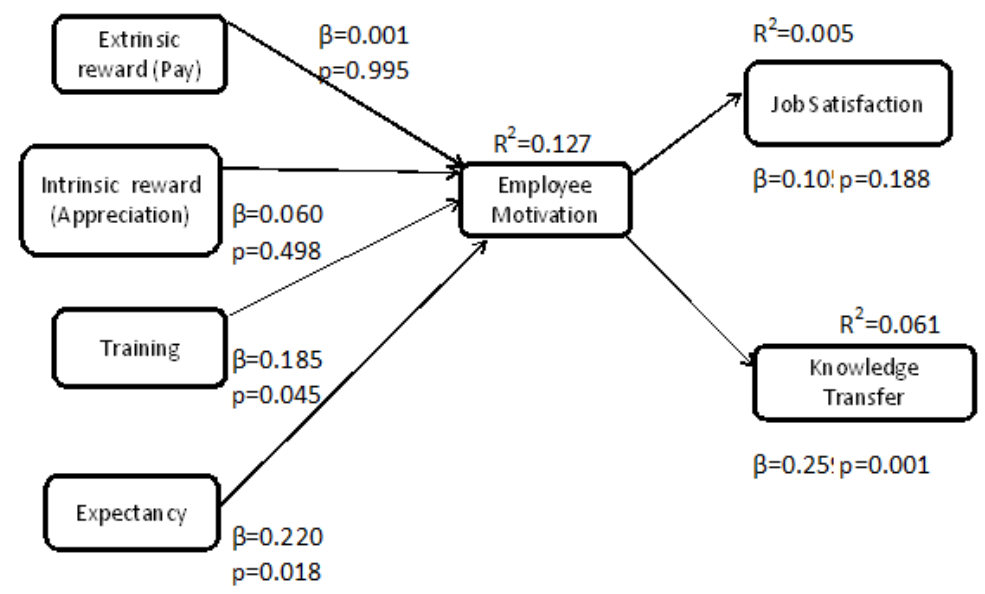

Figure.2 


\section{Discussion and Conclusion}

The main purpose of this study is to observe the relationship of employee motivation with pay, appreciation, training, expectancy, job satisfaction and knowledge transfer. Employee motivation is the main variable of this study which is affected by some specific factors as specified above this section. The literature review of all variables based on the previous theories of some known and qualified researchers. The model is truly developed by us but the bases was taken by the study of these researchers: Butkus and Green (1999), Baron (1893), Bishop (1987), Chiaburu \& Tekleab (2005) Luthans (1998), Moser (1997), Lucas and Ogilvie (2006), Vroom (1964), Ajila (2004). After developing hypothesis on the bases of literature review, in this study we develop a self-administrated questionnaire on the bases of prior published studies and qualified researches. For collection of data, survey was done by us. We distributed 200 questionnaires in Pakistan and from these 160 questionnaires were selected for final analysis. This study is truly based on employees from Pakistan.

This study supports the results of the hypothesis. Results show that employee motivation has influenced by some particular factors. Employee thinking, perception and feelings have much influence on motivation inside the organization. Employee will perceive his motivation by expectations of job and organization.

Rewards are not directly effecting the employee motivation in some organizations. Employees have no concern with rewards. Reward has an insignificant impact on employee motivation. As results shows; extrinsic reward (pay) and intrinsic reward (appreciation) have insignificant relationship with employee motivation. Reward system should be based on individual performance not in totality.

Training has positive impact on employee motivation. It has significant relation and impact on employee motivation. Employee will more motivate in presence of training. In training organizations have to teach them about their job and organization culture. It will create confidence in employees and they will do their work with full interest. It will create a positive influence as hypothesis result shows. Expectancy is the apparent chance that effort goes to good presentation; variables affecting the individual's expectancy discernment include self-efficacy, goal difficulty, and perceived control. We get the targeted performance through expectancy the basis of experience and knowledge. Expectancy usually is supported by tentative verification (Tien, 2000; Vansteenkiste et al., 2005)and it is normally used theories of motivation in the workplace/organization (Campbell and Pritchard, 1976; Henemne and Schwab, 1972; Mitchell and Biglan, 1971) employee motivation play important role in job performance, So result shows, expectancy will create a positive significant relationship with employee motivation.

Job satisfaction is employee's perception that how their job provide them with those things they consider important for them. Job satisfaction has no direct impact to motivate employees. As results shows, job satisfaction has an insignificant relationship with employee motivation. Knowledge transfer is necessary for efficient management as knowledge transfer enable employees to work together efficiently. As knowledge transfer is the source of enhancing organization1s efficiency so managers should encourage their employees. Knowledge 
transfer has a direct impact on employee motivation. As results shows, knowledge transfer has a positive significant relationship with employee motivation.

\section{Limitations / future study}

If employee will be more attach with his job and his performance will be positively influence the organizational performance. The variation in results can be due to change in worth, social circle, expectations and country. As our sample size is small so deviation takes place. There were some limits in study but we can say that it is a good addition in the field of this research. And these limits can be reduced by future study on all these variables.

\section{References}

1. Ajila, C and Abiola, A. (2004). Influence of Rewards on Workers Performance in an Organization, Journal of Social Science, 8(1), pp.7-12

2. Adeyemo, D.A., \& Aremu, A.O. (1999). Career commitment among secondary school teachers in Oyo state, Nigeria: The Role of biographical mediators. Nigerian Journal of Applied Psychology, 5(2), 184-194.

3. Burke, W.W. (2002). Organizational Change: Theory and Practice. Sage: Thousand Oaks.

4. Baron, R. A. (1983). Behavior in organizations, p. 123, New York: Allyn \& Bacon, Inc.

5. Bishop, J. (1987). The recognition \& Reward of Employee Performance, Journal of Labor Economics Vol. 5, No. 4 Part 2: The New Economics of Personnel pp. S36-S56.

6. Basset-Jones, N. and Lloyd, G.F. (2005), "Does Herzberg's motivation theory have staying power?” The Journal of Management Development, Vol. 24, pp. 929-43.

7. Chiaburu, D.S. and Tekleab, A.G. (2005), "Individual and contextual influences on multiple dimensions of training effectiveness", Journal of European Industrial Training, Vol. 29 No. 8, pp. 604-26.

8. Carraher, R, Gibson, A. \& Buckley R (2006). Compensation in the Baltic and the USA, Baltic Journal of Management Vol. 1, pp 7-23.

9. Chen, T.Y., Chang, P.L. and Yen, C.W. (2004), "A study of career needs, career development programs, job satisfaction and the turnover intensity of $\mathrm{R} \& \mathrm{D}$ personnel", Career Development International, Vol. 9 No. 4, pp. 424-37.

10. Campbell, J.P., Pritchard, R.D., 1976. Motivation theory in industrial and organizational psychology. In: Dunnette, M.D., Hough, L.M. (Eds.), Handbook of Industrial and Organizational Psychology. Wiley, New York, pp. 63-130.

11. Chen, Y., Lou, H., 2002. Toward an understanding of the behavioral intention to use a groupware application. Journal of End User Computing 14, 1-16. 
12. Deeprose, D. (1994). How to recognize and reward employees. New York: AMACOM.

13. Eby, L.T., Freeman, D.M., Rush, M.C., \& Lance, C.E. (1999). Motivational bases of affective organizational commitment: A partial test of an integrative theoretical model. Journal of Occupational and Organizational Psychology, 72(4), 463-483.

14. Frey. B. (1997). On the Relationship between Intrinsic and Extrinsic Work Motivation. International Journal of Industrial Organization, 15, p 427 - 439.

15. Gartner, K.N. and Nollen, S.D. (1989), "Career experiences, perceptions of employment practices and psychological commitment to the organisation", Human Relations, Vol. 42, pp. 975-91.

16. Huysman, M. and de Wit, D. (2004), "Practices of managing knowledge sharing: towards a second wave of knowledge management", Knowledge and Process Management, Vol. 11 No. 2, pp. 81-92.

17. Harrison, R. (2000), Employee Development, Beekman Publishing, Silver Lakes, Pretoria.

18. Herzberg, F. (2003), “One more time: how do you motivate employees?”, Harvard Business Review on Motivating People, Harvard Business School Press, Boston, MA, pp. 45-72.

19. Katz, R., \& Van Maanan, J. (1977). The loci of work satisfaction: Job interaction and policy. Human Relations, 30, 469-486.

20. Luthans, F. (1998). Organizational Behavior. Boston: Irwin McGraw-Hill. Luthans, Fred, Harriette S. McCaul, Nancy G. Dodd (1985). Organizational Commitment: A Comparison of American, Japanese, and Korean Employees, The Academy of Management Journal, 28(1), pp.213-219.

21. Landy, F.J., Becker, W.S., 1990. Motivation theory reconsidered. In: Staw, B.M., Cummings, L.L. (Eds.), Work in Organizations. Jai Press, Greenwich, CT, pp. $1-38$.

22. Locke, E. A. (1976). The nature and causes of job satisfaction. In M. D. Dunnette (Ed.), Handbook of industrial and organizational psychology (pp.1297-1349). Chicago: Rand McNally.

23. Lawler, E. E. (2003). Treat people right. San Francisco: Jossey-Bass Inc. McGraw-Hill Irwin.

24. Lang, D.L. (1992), “Organizational culture and commitment”, Human Resource Development Quarterly, Vol. 3 No. 2, pp. 191-6.

25. Lucas, L.M. and Ogilvie, D. (2006), “Things are not always what they seem. How reputations, culture and incentives influence knowledge transfer", The Learning Organization, Vol. 13 No. 1, pp. 7-24. 
26. Meyer, J. and Allen, N. (1991), "A three component conceptualization of organizational commitment", Human Resource Management Review, Vol. 1 No. 1, pp. 61-90.

27. Moser, K. (1997). Commitment in organizations. Psychologies, 41 (4), pp.160-170.

28. Mitchell, T.R., 1974. Expectancy models of job satisfaction, occupational preference and effort: a theoretical, methodological and empirical appraisal. Psychological Bulletin 81, 1053-1077.

29. Mottaz, C.J. (1985). The relative importance of intrinsic and extrinsic rewards as determinants of work satisfaction. The Sociological Quarterly, 26(3), 365-385.

30. Malhotra, N., Budhwar, P., \& Prowse, P. (2007). Linking rewards to commitment: An empirical investigation of four UK call centres. International Journal of Human Resource Management, 18(12), 2095-2017.

31. Porter, L.W., \& Lawler, E.E. (1968). Managerial Attitudes and Performance. Homewood, IL: Dorsey Press.

32. Roomkin, M.J. and Weisbrod, B.A. (1999), "Managerial compensation and incentives in for-profit and non-profit hospitals", Journal of Law, Economics, and Organization, Vol. 15 No. 3, pp. 750-81.

33. Rowden, R.W. and Conine, C.T. Jr (2005), “The impact of workplace learning and job satisfaction in small US commercial banks", Journal of workplace Learning, Vol. 17 No. 4, pp. 215-30.

34. Reio, G, T. \& Callahon, J. L. (2004). Affect, Curiosity, and socialization-related Learning; a path analysis of antecedents to job performance, Journal of Business and Psychology, Vol.19, pp3-22.

35. Rusbult, C. E., Farrell, D., Rogers, D., \& Mainous, A. G. (1988). Impact of exchange variables on exit, voice, loyalty, and neglect: An integrative model of responses to declining job satisfaction. Academy of Management Journal, 31(3), pp.599-627.

36. Simons, T., Enz, C.A., 1995. Motivating hotel employees. The Cornell Hotel and Restaurant Administration Quarterly. 36 (1), 20-27.

37. Siu, V., Tsang, N., Wong, S., 1997. What motivates Hong Kong's hotel employees? The Cornell Hotel and Restaurant Administration Quarterly 38 (5), 44-49.

38. Swart, J., Mann, C., Brown, S. and Price, A. (2005), Human Resource Development: Strategy and Tactics, Elsevier Butterworth-Heinemann Publications, Oxford. Art

39. Tien, F.F., 2000. To what degree does the desire for promotion motivate faculty to perform research? Testing the expectancy theory. Research in Higher Education 
$41(6), 723-752$.

40. Tsai, P., Yen, C.Y., Huang, L. and Huang, I. (2007), "A study on motivating employee's learning commitment in the post-downsizing era: job satisfaction perspective", Journal of World Business, Vol. 42 No. 2, pp. 157-69.

41. Vroom, V.H., 1964. Work and Motivation. Wiley, New York. Wahba, M., House, R., 1974. Expectancy theory in work and motivation: some logical and methodological issues. Human Relations 27, 121-147.

42. Vansteenkiste, M., Lens, W., De Witte, H., Feather, N.T., 2005. Understanding unemployed people's job search behavior, unemployment experience and well-being: a comparison of expectancy-value theory and self-determination theory. British Journal of Social Psychology 44 (2), 268-286.

43. Van Eerde, W., Thierry, H., 1996. Vroom's expectancy models and work related criteria: a meta-analysis. Journal of Applied Psychology 81 (5), 575-586.

44. Rizwan, M., Javeed, K., Nawaz, M. I., Erum, A., Afzal, S., Azam, S. \& Rehman, A. (2013) A descriptive study to explore relationship between HR practices and employee performance in private banks of Pakistan. Journal of Basic and Applied Scientific Research, 3(12), 225-234 